\title{
CHARACTERIZATION OF A CLONE FROM AN ADULT WORM CDNA LIBRARY SELECTED WITH ANTI- Schistosoma mansoni HUMAN ANTIBODIES DISSOCIATED FROM IMMUNE COMPLEXES: A PRELIMINARY REPORT
}

\begin{abstract}
SUMMARY
Considering the scarcity of defined antigens, actually useful and reliable for use in the field studies, we propose an alternative method for selection of cDNA clones with potential use in the diagnosis of schistosomiasis. Human antibodies specific to a protein fraction of 31/32 $\mathrm{kDa}(\mathrm{Sm} 31 / 32)$, dissociated from immune complexes, are used for screening of clones from an adult worm cDNA library. Partial sequencing of five clones, selected through this strategy, showed to be related to Schistosoma mansoni: two were identified as homologous to heat shock protein 70 , one to glutathione S-transferase, one to homeodomain protein, and one to a previously described EST (expressed sequence tag) of $S$. mansoni. This last clone was the most consistently reactive during the screening process with the anti-Sm31/32 antibodies dissociated from the immune complexes. The complete sequence of this clone was obtained and the translation data yielded only one ORF (open reading frame) that code for a protein with 57 amino acids. Based on this amino acid sequence two peptides were chemically synthesized and evaluated separately against a pool of serum samples from schistosomiasis patients and non-schistosomiasis individuals. Both peptides showed strong reactivity only against the positive pool, suggesting that these peptides may be useful as antigens for the diagnosis of schistosomiasis mansoni.
\end{abstract}

KEYWORDS: Schistosoma mansoni; cDNA library; Immunoscreening; DNA sequencing, Synthetic peptides.

Satisfactory diagnostic techniques are prerequisite for the success of schistosomiasis control programs in endemic areas. Parasitological techniques lack sensitivity and serologic tests have been suggested to be incorporated for the diagnosis of schistosomiasis, especially in areas of low prevalence ${ }^{3}$. Improvement of the immunodiagnostic tools depends on the production of specific and sensitive antigens in sufficient amount to provide low cost assays. As already applied to different infectious diseases, some recombinant proteins and synthetic peptides might be used as immunogenic and specific antigens for diagnostic purposes in schistosomiasis ${ }^{6}$. In general, the use of various specific epitopes, in the same diagnostic method, can improve the sensitivity without interfering with the specificity.

The aim of this work, was the characterization of a protein fraction of the adult worm antigen (AWA) preparation, called Sm31/32, composed by two highly immunogenic exoantigens, cathepsin $\mathrm{B}$ and asparpaginyl endopeptidase, respectively $31 \mathrm{kDa}$ and $32 \mathrm{kDa}$ molecules ${ }^{1,5}$. S. mansoni cDNA clones were selected through an alternative method, by using human antibodies against $\mathrm{Sm} 31 / 32$ fraction for screening of an adult worm cDNA expression library ${ }^{4}$.

The characterization of the selected clones showed one (ET03), which was the most consistently reactive during the screening process with the anti-Sm31/32 antibodies.

This clone was homologous to a previously described EST (expressed sequence tag) of S. mansoni, called MA002456.C8F (Bailey et al., unpublished data) and deposited on "GenBank" in February, 1999 (Access number 2191547).

Briefly, AWA was submitted to $12.5 \%$ sodium dodecyl sulfatepolyacrylamide gel electrophoresis and electrotransferred onto nitrocellulose membrane (NCM), which was cut on the upper and lower position of the Sm31/32 migration region. Then, the NCM containing the Sm31/32 fraction was blocked by immersion for two hours, at $25^{\circ} \mathrm{C}$, in $0.01 \mathrm{M}$ phosphate buffered saline (PBS), containing $5 \%$ skin milk (PBS-milk). The strips were washed twice with PBS and incubated overnight with a pool of serum samples obtained from schistosomiasis patients. After six washes in PBS and three washes in $1 \mathrm{M} \mathrm{NaCl}$ solution, the antibodies were eluted from the $\mathrm{NCM}$ by treatment with $0.1 \mathrm{M}$ glycine- $\mathrm{HCl}, \mathrm{pH} 2.6\left(15 \mathrm{~min}, 20^{\circ} \mathrm{C}\right)$. After neutralization with $1 \mathrm{M}$ Tris-Cl, pH $8.0\left(15 \mathrm{~min}, 20^{\circ} \mathrm{C}\right)$, the eluted antibodies were used for immunoscreening as described ${ }^{2}$. Approximately 300,000 plaques from the adult worm cDNA library were screened after inducing the phage 


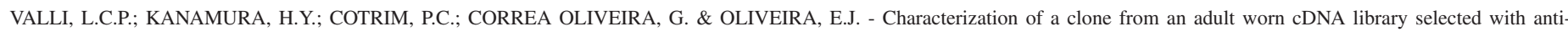
Schistosoma mansoni human antibodies dissociated from immune complexes: a preliminary report. Rev. Inst. Med. trop. S. Paulo, 49(3): 187-189, 2007.

with $10 \mathrm{mM}$ isopropyl-D-thioglactoside (IPTG), for three hours, at $37^{\circ} \mathrm{C}$. The plaque blots on the filter papers, after being blocked with PBS-milk (two h, $25^{\circ} \mathrm{C}$ ), were washed thoroughly with PBS containing $0.05 \%$ Tween 20 (PBS-Tween) and incubated overnight with the eluted anti-Sm31/32 antibodies. After new washes with PBS-Tween, the filter papers were incubated with peroxidase-labelled anti-human IgG antibodies, for two hours at room temperature, washed again, and then colour reaction was developed with a substrate solution containing 4-cloro-1 naftol and $\mathrm{H}_{2} \mathrm{O}_{2}$. Bluescript SK-plasmids containing the recombinant inserts were excised in vivo using an excision kit, and the plasmids DNA were purified using the Qiagen kit (Chatsworth CA, USA).

Partial DNA sequences of five clones, consistently immunoreactive with the eluted antibodies, were obtained by use of an ABI Prism automated sequencer. Two were identified as homologous to heat shock protein 70 (HSP-70), one to glutathione S-transferase (GST), one to homeodomain protein ${ }^{7}$, and one only to a previously described EST (expressed sequence tag) of $S$. mansoni. The nucleotide and derived amino acid sequences of ET03 clone are shown in Fig. 1.

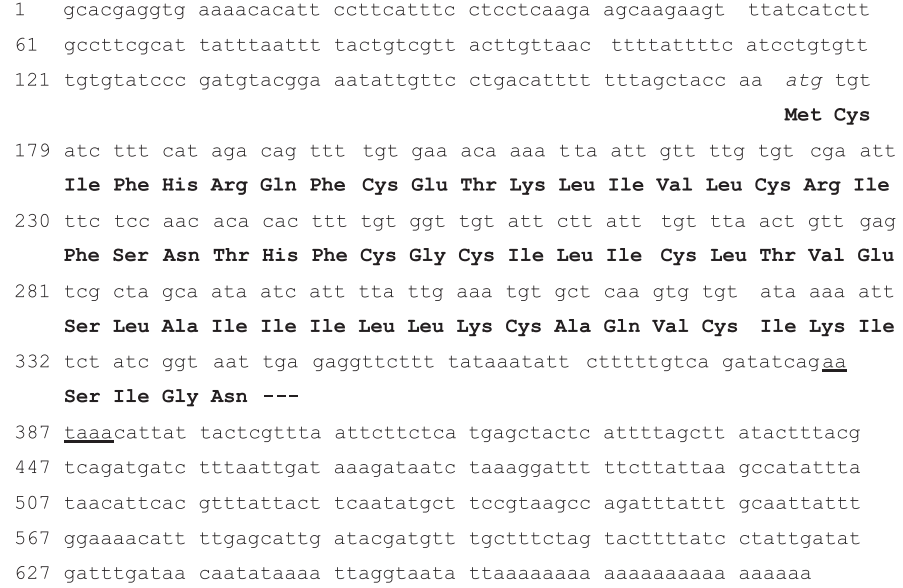

Fig. 1 - Nucleotide sequence and predicted amino acid sequences of the ET03clone. Putative polyadenylation signal is underlined.

This recombinant clone had an insert size of $682 \mathrm{bp}$. The complete sequence and the translation data of ET03 clone, which was the most reactive, yielded only an open reading frame (ORF) that coded for a protein with 57 amino acids, with predictive molecular weight and $\mathrm{pI}$ of $6.3 \mathrm{kDa}$ and 8.52 , respectively.

Once we had no success in the expression of this small protein, two peptides P1 (HRQFCETKLIVLCRIFSNTH) and P2 (TVESLAIIILLKCAQVCIKI), corresponding to the amino acids positions 5-24 and 35-53 of the ORF were obtained using the f-moc strategy, in a peptide synthesizer ABI 433A Applied Biosystems (Foster City, CA, USA). The corresponding peptides were purified by RTHPLC, through Waters Delta Pak C18 column (19 mm x 300 mm, 15 microns, 300 angstroms pore size, $5 \mu \mathrm{m}$ particle size) and identified and characterized by mass spectrometry Voyager DE-RP MALDI-TOF Applied Biosystems (Foster City, CA, USA).
These peptides were tested by ELISA, on microtiter plates (Costar 3590), against a pool of serum samples obtained from schistosomiasis patients (positive pool) and normal individuals (negative pool). P1 and P2 showed strong reactivity only against the positive pool (Fig. 2), suggesting that these peptides may be useful as antigens in immunological methods for the diagnosis of schistosomiasis mansoni.

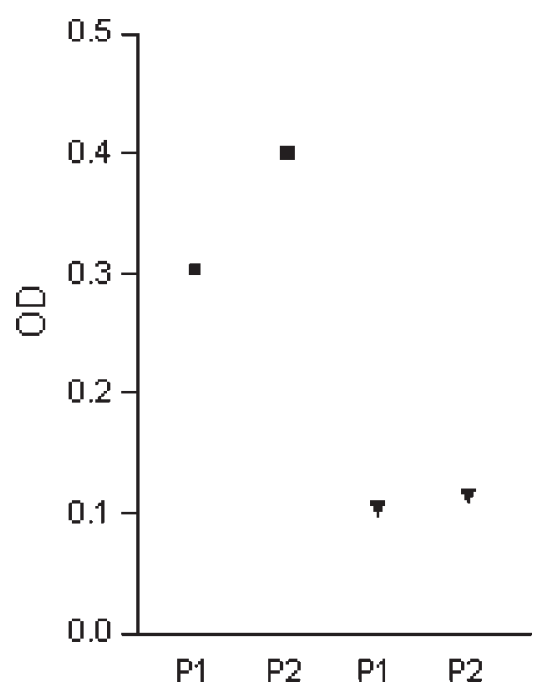

Fig. 2 - Optical density (OD) readings for the P1 and P2 peptides, in the ELISA test with schistosomiasis positive $(\boldsymbol{\square})$ and negative $(\boldsymbol{\nabla})$ control sera pool.

\section{RESUMO}

Caracterização de um clone selecionado a partir de biblioteca de cDNA de verme adulto com anticorpos anti-Schistosoma mansoni dissociados de imunocomplexos

Considerando a escassez de antígenos quimicamente definidos, realmente úteis e confiáveis para aplicação na soroepidemiologia da esquistossomose em larga escala, foi proposto, neste trabalho, um método alternativo para a seleção de clones de cDNA que expressam proteínas com putativo potencial diagnóstico na esquistossomose. Empregando anticorpos específicos contra uma fração proteica de 31/ $32 \mathrm{kDa}(\mathrm{Sm} 31 / 32)$, purificados através da dissociação de imunocomplexos, foram selecionados cinco clones de cDNA a partir de genoteca de verme adulto de Schistosoma mansoni. O seqüenciamento parcial destes clones demonstrou que todos eram relacionados ao $S$. mansoni: dois apresentaram homologia com a proteína de choque térmico de $70 \mathrm{kDa}$ e os demais com glutationa S-transferase, "homeodomain protein" e uma etiqueta de sequiência expressa (EST). Este último foi o clone que melhor reagiu, durante o processo de seleção, com os anticorpos anti-Sm31/32 dissociados de imunocomplexos. Baseado na sequiência de aminoácidos deste clone, dois peptídeos foram quimicamente sintetizados e analisados separadamente frente a misturas de soros de indivíduos normais e de pacientes com esquistossomose mansoni. Ambos os peptídeos demonstraram uma intensa reatividade somente contra a mistura de soros positivos, sugerindo que estes peptídeos podem ser úteis como antígenos para o diagnóstico da esquistossomose mansoni. 


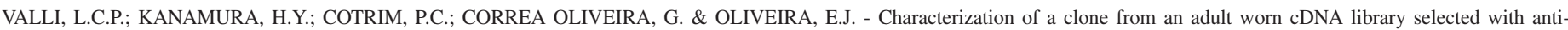
Schistosoma mansoni human antibodies dissociated from immune complexes: a preliminary report. Rev. Inst. Med. trop. S. Paulo, 49(3): $187-189,2007$.

\section{REFERENCES}

1. DALTON, J.P.; HOLA-JAMRISKA, L. \& BRINDLEY, P.J. - Asparaginyl endopeptidase activity in adult Schistosoma mansoni. Parasitology, 111: 575-580, 1995.

2. HALL, R.; HYDE, J.E.; GOMAN, M. et al. - Major surface antigen gene of a human malaria parasite cloned and expressed in bacteria. Nature, 311: 379-382, 1984.

3. KANAMURA, H.Y.; SILVA, R.M.; CHIODELLI, S.G.; GLASSER, C.M. \& DIAS, L.C. - IgM-immunofluorescence test as a diagnostic tool for epidemiologic studies of schistosomiasis in low endemic areas. Mem. Inst. Oswaldo Cruz, 97: 485-489, 2002 .

4. KANAMURA, H.Y. \& HANCOCK, K. - Rapid characterization of S. mansoni expression library clones of potential interest. Rev. Inst. Med. trop. S. Paulo, 39: 355-357, 1997.
5. KLINKERT, M.Q.; FELLEISEN, R.; LINK, G.; RUPPEL, A. \& BECK, E. - Primary structures of Sm 31/32 diagnostic proteins of Schistosoma mansoni and their identification as proteases. Molec. Biochem. Parasit., 33: 113 -122, 1989.

6. LOSADA, S.; CHACON, N.; COMENARES, C. et al. - Schistosoma: cross-reactivity and antigenic community among different species. Exp. Parasit., 111: 182-190, 2005.

7. WEBSTER, P.J. \& MANSOUR, T.E. - Conserved classes of homeodomains in Schistosoma mansoni, an early bilateral metazoan. Mech. Dev., 38: 25-32, 1992.

Received: 20 December 2005

Accepted: 31 October 2006 